\title{
Health promotion programs related to the Athens 2004 Olympic and Para Olympic games
}

\author{
Elpidoforos S Soteriades 1,2,3, Christos Hadjichristodoulou 3,4, \\ Jeni Kremastinou ${ }^{4}$, Fotini C Chelvatzoglou ${ }^{5}$, Panagiotis S Minogiannis ${ }^{6}$ and \\ Matthew E Falagas*1,5,7
}

\begin{abstract}
Address: ${ }^{1}$ Alfa Institute of Biomedical Sciences (AIBS), Athens, Greece, ${ }^{2}$ Cyprus International Institute for the Environment and Public Health in Association with Harvard School of Public Health, Nicosia, Cyprus, ${ }^{3}$ Department of Hygiene and Epidemiology, Medical Faculty, University of Thessaly, Larisa, Greece, ${ }^{4}$ National School of Public Health - Olympic Planning Unit (OPU), Athens, Greece, ${ }^{5}$ Department of Medicine, "Henry Dunant" Hospital, Athens, Greece, ${ }^{6}$ Health Services, Athens 2004 Olympic Games Organizing Committee, Greece and ${ }^{7}$ Department of Medicine, Tufts University School of Medicine, Boston, Massachusetts, USA

Email: Elpidoforos S Soteriades - esoteria@cyprusinstitute.org; Christos Hadjichristodoulou - xhatzi@med.uth.gr; Jeni Kremastinou - jkrem@otenet.gr; Fotini C Chelvatzoglou - f.helvatzoglou@aibs.gr; Panagiotis S Minogiannis - pminogiannis@hotmail.com; Matthew E Falagas* - m.falagas@aibs.gr

* Corresponding author
\end{abstract}

Published: 24 February 2006

BMC Public Health 2006, 6:47 doi:10.1 I86/147/-2458-6-47

This article is available from: http://www.biomedcentral.com/I47/-2458/6/47

(c) 2006 Soteriades et al; licensee BioMed Central Ltd.

This is an Open Access article distributed under the terms of the Creative Commons Attribution License (http://creativecommons.org/licenses/by/2.0), which permits unrestricted use, distribution, and reproduction in any medium, provided the original work is properly cited.
Received: 3I August 2005

Accepted: 24 February 2006

\begin{abstract}
Background: The Olympic Games constitute a first-class opportunity to promote athleticism and health messages. Little is known, however on the impact of Olympic Games on the development of health-promotion programs for the general population.

Our objective was to identify and describe the population-based health-promotion programs implemented in relation to the Athens 2004 Olympic and Para Olympic Games.
\end{abstract}

Methods: A cross-sectional survey of all stakeholders of the Games, including the Athens 2004 Organizing Committee, all ministries of the Greek government, the National School of Public Health, all municipalities hosting Olympic events and all official private sponsors of the Games, was conducted after the conclusion of the Games.

Results: A total of 44 agencies were surveyed, 40 responded ( $91 \%$ ), and ten ( 10$)$ health-promotion programs were identified. Two programs were implemented by the Athens 2004 Organizing Committee, 2 from the Greek ministries, 2 from the National School of Public Health, I from municipalities, and 3 from official private sponsors of the Games. The total cost of the programs was estimated at 943,000 Euros; a relatively small fraction $(0.08 \%)$ of the overall cost of the Games.

Conclusion: Greece has made a small, however, significant step forward, on health promotion, in the context of the Olympic Games. The International Olympic Committee and the future hosting countries, including China, are encouraged to elaborate on this idea and offer the world a promising future for public health. 


\section{Background}

International sporting competitions in general, and the Olympic Games in particular, represent important events, where elite athletes and millions of people from around the world gather together to celebrate athleticism[1,2]. At the same time, mass media broadcasting of the Olympic Games to billions of people worldwide constitute a powerful tool through which messages on athletic values and health promoting habits and lifestyles may be presented[3-5]. Furthermore, the city hosting the Olympic Games is frequented by a large number of visitors from different geographic areas, and provides an ideal setting for health promotion for the visitors as well as the city's local population[6-8]. Thus, international sport events represent a great opportunity for public health professionals to promote healthy messages, though many companies, e.g. the tobacco industry, also take the opportunity to advertise unhealthy products at certain sport events[9$14]$.

Most international sponsorship activities have involved several strategies for health promotion including the promotion of health messages, $[15,16]$ the use of role models,[17] the development of policies that support health behaviors such as the designation of smoke-free areas, $[18,19]$ and physical activity,[20] and the restrictions on tobacco or alcohol sponsorship or cigarette sale[21,22]. In addition to sponsorship activities during sport events, a range of non-sponsorship activities have also been associated with the Olympic Games[23]. Since the first smoke-free Calgary Winter Olympics in 1988, the International Olympic Committee (IOC) has refused sponsorship and publicity from the tobacco industry and all subsequent Games have been labeled smoke-free[24].

Over the past decades, great efforts have been made in identifying and promoting healthy habits in the general population, particularly through sports. [25-27] Smoking, lack of physical activity, and poor diet constitute a host of modifiable risk behaviors that are targeted by public health professionals. Similarly, obesity represents an additional target for public health programs as is dependent on the above unhealthy behaviors. The Olympic Games provide a first-class opportunity to promote healthy messages to the general population and inspire people of all ages to become fit, and improve their health.

The purpose of our study was to evaluate the impact of the Athens 2004 Olympic and Para Olympic Games on the development and implementation of population-based health-promotion programs and related activities for the benefit of the spectators and the local population.

\section{Methods}

A cross-sectional survey was conducted in order to collect information from all potential stakeholders in Greece regarding health promotion programs developed and implemented in relation to the Athens 2004 Olympic and Para Olympic Games. The Athens 2004 Organizing Committee, all ministries of the Greek government, the National School of Public Health, all municipalities that hosted Olympic events and all official private sponsors of the Games were invited to participate in the survey.

Two questionnaires were developed in order to obtain information about health-promotion programs associated with the Olympic and Para Olympic Games one for the sponsors and one for the ministries involved in the organization of the games [see additional files 1 and 2]. Information was collected regarding the type of health promotion program implemented, the population targeted, the cost of each program and the time period covered by each program. In particular, information on physical activity, anti-smoking campaigns, diet, and alcohol consumption was specifically requested. The survey included additional open-ended questions in order to identify other programs that might have been implemented. The survey focused on a time period extending from up to two years prior to the Olympic Games (2002, 2003), until the period of the Olympic Games itself (August 13 ${ }^{\text {th }}-$ September 30th, 2004).

The questionnaire was mailed or faxed to each responsible officer from all above-described agencies, in order for them to review it and gather information with regards to the questions of the survey, in advance of the data collection process. After the distribution of the questionnaire, an investigator contacted each officer from all agencies and completed each survey over the phone or requested a completed survey via facsimile. Repeated phone calls to each responsible officer were placed until an official reply to our request or a non-cooperation statement was provided.

The data collection process was completed four months after the conclusion of the Games. Additional analytic data on the cost of the Games in general and on specific components of the Games in particular were obtained from the Ministry of National Economy.

\section{Results}

A total of 44 agencies were contacted by phone and/or facsimile, 40 agencies completed the questionnaire, and 10 health-promotion programs, implemented prior to, and/ or during the Olympic Games, were identified. The average cost for the implemented programs was about 95,000 Euros $(€)$ with a range between $20,000 €$ and $600,000 €$. The total cost of the health-promotion programs was 
Table I: Health promotion programs implemented prior to and/or during the Athens 2004 Olympic and Para Olympic Games

\begin{tabular}{|c|c|c|c|c|}
\hline Agency & $\begin{array}{l}\text { Number of } \\
\text { Programs }\end{array}$ & Type of Activity (cost) & Time Period & Target Population \\
\hline $\begin{array}{l}\text { Athens } 2004 \text { Organizing } \\
\text { Committee }\end{array}$ & Two (2) & $\begin{array}{l}\text { 1. Non-smoking policy }(€ 25,000) \\
\text { 2. Free distribution of condoms }(€ 25,000)\end{array}$ & $\begin{array}{l}\text { I. For two years prior to, } \\
\text { and during the Games } \\
\text { 2. During the Games }\end{array}$ & $\begin{array}{l}\text { I. Spectators, volunteers, } \\
\text { and staff of AOC } \\
\text { 2. Everyone who had } \\
\text { access to the Olympic } \\
\text { village }\end{array}$ \\
\hline $\begin{array}{l}\text { Ministries of the Greek } \\
\text { Government }\end{array}$ & Two (2) & $\begin{array}{l}\text { I. Brochures and CD- ROM (three } \\
\text { languages) to promote the Mediterranean } \\
\text { diet. Exhibit of traditional food products } \\
\text { (€28,000) } \\
\text { 2. Brochure with travel-related health } \\
\text { information about Greece }(€ 20,000)\end{array}$ & $\begin{array}{l}\text { I. For six months prior to } \\
\text { the Olympic Games and } \\
\text { during the Olympic period } \\
\text { 2. During the } \\
\text { OlympicPeriod }\end{array}$ & $\begin{array}{l}\text { I. Journalists and the } \\
\text { general population } \\
\text { 2. Visitors of Greece }\end{array}$ \\
\hline $\begin{array}{l}\text { The National School of } \\
\text { Public Health }\end{array}$ & Two (2) & $\begin{array}{l}\text { I. Brochure/Posters on how to prevent } \\
\text { heat disorders }(€ \mid 0,000) \\
\text { 2. Brochure for healthy swimming } \\
(€ \mid 5,000)\end{array}$ & $\begin{array}{l}\text { I. For three months prior } \\
\text { to, and during the Olympic } \\
\text { period } \\
\text { 2. During the Olympic } \\
\text { Period }\end{array}$ & $\begin{array}{l}\text { 1. Athletes, visitors and the } \\
\text { general population } \\
\text { 2. Visitors and the general } \\
\text { population }\end{array}$ \\
\hline $\begin{array}{l}\text { Municipalities Hosting } \\
\text { Olympic Events }\end{array}$ & One (I) & I. Brochure on healthy cities $(€ 60,000)$ & $\begin{array}{l}\text { I. For two years prior to } \\
\text { the Games }\end{array}$ & I. The general population \\
\hline $\begin{array}{l}\text { Official Private Sponsors of } \\
\text { the Games }\end{array}$ & Three (3) & $\begin{array}{l}\text { I. Brochures and TV/Radio } \\
\text { advertisements on physical activity (N/A) } \\
\text { 2. Brochures, TV/Radio advertisements, } \\
\text { and lectures on physical activity and the } \\
\text { Olympic Games }(€ 600,000) \\
\text { 3. Brochure on diet }(N / A)\end{array}$ & $\begin{array}{l}\text { I. For two years prior to, } \\
\text { and during the Games } \\
\text { 2. For two years prior to, } \\
\text { and during the Games } \\
\text { 3. For one year prior to } \\
\text { the Games }\end{array}$ & $\begin{array}{l}\text { I. The general population, } \\
\text { spectators, students, and } \\
\text { women } \\
\text { 2. School students } \\
\text { 3. School students }\end{array}$ \\
\hline
\end{tabular}

about $943,000 €$, and constituted a small fraction $(0.08 \%)$ of the overall cost of the games, even after excluding the cost of construction, preparation of athletic facilities, and security.

The Athens 2004 Olympic Games Organizing Committee implemented two programs: (a) a non-smoking policy in all premises related to the Organizing Committee and (b) the distribution of condoms, free of charge, in the Olympic Village Polyclinic. In the Table, we describe the different programs implemented along with the responsible agency, the type of activity, the time period covered and the target population. The vast majority of the programs included the development and distribution of brochures on several health-related topics targeting visitors, spectators of the Games, and the general population.

\section{Discussion}

Greece is one of the financially weakest and demographically smallest countries ever managed to organize the Olympic Games in a quite successful way. Despite significant shortage of funds and financial strain on the country's budget, several agencies devoted some resources on health-promotion programs implemented prior to and during the Olympic Games for the benefit of visitors, spectators, and the general population. While the cost of the implemented programs was limited compared to the total expenses of the Games, we believe that it offers a hopeful seed for the future.
There are limited reports in the medical literature on the development and implementation of health-promotion programs related to sporting events in general $[10,11,18,20,22,26]$ and the Olympic Games in particu$\operatorname{lar}[23,28]$. Many competitions take place all over the world, however the benefit to each hosting country's population remains unclear[29-31]. Although more programs could have been developed, the Athens 2004 Olympic Games offered a small, nevertheless, important example to be expanded and build upon in the future, in order to diffuse health messages, and encourage healthy habits in the general population in the period leading to the Games, as well as during the Olympic Games[32].

Developing effective and sustainable health promotion programs in relation to the Olympic Games remains an important challenge for public health professionals around the world. Each country undertakes significant economic investments to organize the Olympic Games. Therefore it would be instrumental to include health promotion programs as a high priority in the overall strategic planning for the Games. Each organizing country along with the International Olympic Committee could work together in developing population-based programs such as competitions for the lay public, promotion of healthy life styles through athletes acting as role models, development of exercise fields and stadiums in underdeveloped areas etc. Perhaps such health promotion programs with appropriate scoring criteria should be incorporated into 
the application and evaluation process of candidate cities and countries for the prospective organization of Olympic Games.

Our study was limited in scope and despite obtaining information in a cross-sectional fashion our data collection covered a period of two years in a retrospective fashion. Although, a large number of public and private agencies were surveyed, it is possible that we might have missed some information, which could have resulted in underestimation of implemented health-promotion programs. In addition, information on the cost of the different programs may not reflect accurate economic reports since we relied on the information reported in the questionnaire.

Our findings suggest that there is significant room for improvement in the development and implementation of health-promotion programs during sport events. The organization of the Olympic Games, constitute an excellent opportunity for public health professionals to promote health in the general population of the hosting country and distribute such messages around the world. "Whenever there is a will there's a way" as evidenced by the institutional policies developed by the International Olympic Committee regarding doping and smoke-free areas[33-36]. Greece has made a small, however, significant step forward on health promotion in relation to the Olympic Games. The International Olympic Committee and China are encouraged and expected to elaborate on this idea and offer the world a promising future for public health.

\section{Competing interests}

The author(s) declare that they have no competing interests.

\section{Authors' contributions}

ESS conceived of the study, and participated in its design and coordination. ESS, $\mathrm{CH}, \mathrm{JK}$, and MEF developed the questionnaires. ESS, CH, JK, FCC, and PSM collected the data. ESS drafted the manuscript. All authors made contributions to the text and read and approved the final manuscript.

\section{Additional material}

\section{Additional File 1}

Questionnaire on Health Promotion Programs Related to the Athens 2004 OlympicGames (Ministries, Government Agencies)

Click here for file

[http://www.biomedcentral.com/content/supplementary/1471-

2458-6-47-S1.doc]

\section{Additional File 2}

Questionnaire on Health Promotion Programs Related to the Athens 2004 OlympicGames (Sponsors)

Click here for file

[http://www.biomedcentral.com/content/supplementary/14712458-6-47-S2.doc]

\section{Acknowledgements}

We would like to thank the representatives of the different agencies, who devoted their time to collect the data and complete the questionnaire. We would also like to thank Ms. Antonia Karavasiou for her help in this project.

\section{References}

I. Kennedy D: Here come the Olympics. Science 2004, 305:573.

2. Hu K: Special Olympics, Special Smiles. Hawaii Dent J 2004, 35:16.

3. Lavack AM: Message content of alcohol moderation TV commercials: impact of corporate versus nonprofit sponsorship. Health Mark Q 1999, I6:15-3I.

4. Schmuck C: Broadcasts for a billion: the growth of commercial television in China. Columbia J World Bus 1987, 22:27-34.

5. Koshi J: 'Which sports get more TV coverage for their sponsors?'. Campaign 1981. August 12(15a)

6. Buckley NA, Dobbins TA, Parsons M, Dawson AH: A drug-free Olympics - a goal for spectators as well as athletes. Med J Aust 1996, I 65:682-3.

7. Wilks J: International tourists, motor vehicles and road safety: a review of the literature leading up to the Sydney 2000 Olympics. J Travel Med 1999, 6: I15-21.

8. Rees T: Utah healthcare system watches over Olympians and spectators. Profiles Healthc Mark 2002, I 8: I, 4-5, 3.

9. Holman CD, Donovan RJ, Corti B, Jalleh G, Frizzell SK, Carroll AM: Banning tobacco sponsorship: replacing tobacco with health messages and creating health-promoting environments. Tob Control 1997, 6: I I5-21.

10. Corti B, Donovan RJ, Holman CD, Coten N, Jones SJ: sponsorship to promote health messages to children. Health Educ Behav 1997, 24:276-86.

II. Blom ED: Tobacco free at the Indianapolis 500. Indiana Med 1996, 89:207-9.

12. Assunta M: BAT flouts tobacco-free World Cup policy. Tob Control 2002, I I:277-8.

13. Giles-Corti B, Donovan RJ, Frizzell S, Jalleh G, Clarkson J: Increasing the reach of health sponsorship: using a "sponsorship kit" to promote health. Am J Health Promot 2000, I 5: I 26-9. iii

14. Chapman S: Formula one racing and the end of tobacco sponsorship: half pregnant at 350 kph? Tob Control 2002, I I:87-8.

15. World Health Organization: Prevention and Health Promotion Messages through Sponsorship of Sports and Cultural Events. Tobacco Alert. World No-Tobacco Day Special Issue Advisory Kit 1996.

16. Hastings GB, MacAskill S, McNeill RES, Leathar DS: Sports Sponsorship in Health Promotion. Health Promotion 1988, 3:161-I69.

17. Anonymous: Health professionals agree to become non-smoking role models. S Afr Med J 2004, 94:256.

18. Jones S, Corti B, Donovan RJ, Holman CD, Dennis JR: Public response to a smoke-free policy at a major sporting venue. Med J Aust 1996, I 64:759.

19. Corti B, Holman CD, Donovan RJ, Coten NJ, Dennis JR, Frizzell SK, Carroll AM: Public attitudes to smoke-free areas in sports venues. Med J Aust 1995, 162:612.

20. Nutbeam D, Catford J: Health promotion. An exercise in sponsorship. Health Soc Serv J 1 985, 95:73.

21. Nakajima DH: Message from the World Health Organization for World No-Tobacco Day I 996:'Sport and the arts without tobacco'. TobaccoAlert. World No-Tobacco Day Special Issue Advisory Kit 1996. 
22. Giesbrecht N, Greenfield TK: Public opinions on alcohol policy issues: a comparison of American and Canadian surveys. Addiction 1999, 94:52I-31.

23. Prokop L: International Olympic Committee Medical Commission's policies and programs in nutrition and physical fitness. Am J Clin Nutr 1989, 49(5 Suppl): 1065.

24. Villalbi JR, Ballestin M, Serra L, Salto E, Salleras L, Vinue JM: Evaluation of the Smoke-free Olympics Project. Promotion and Education 1994, I:10-13.

25. Giles-Corti B, Donovan RJ, Frizzell S, Jalleh G, Clarkson J: Increasing the reach of health sponsorship: using a "sponsorship kit" to promote health. Am J Health Promot 2000, 15:126-9. iii

26. New Challenges for the Health Sector: Health-promoting Sport, Arts and Racing Settings. Australian National Health and Medical Research Council 1996.

27. Corti B, Holman CD, Donovan RJ, Frizzell S, Carroll AM: Warning: attending a sport, racing or arts venue may be beneficial to your health. Aust N Z J Public Health 1997, 21:37I-6.

28. Villalbi J, Ballestin M, Vinue J, Serra L, Cuervo J, Salleras L: The Barcelona Smoke-free Olympics project. Hygie 1992, I I:24-8.

29. Hogan K, Norton K: The 'price' of Olympic Gold. J Sci Med Sport 2000, 3:203-18.

30. Oddy WH, Holman CD, Corti B, Donovan RJ: Epidemiological measures of participation in community health promotion projects. Int J Epidemiol 1995, 24:1013-21.

3I. Holman CD, Donovan RJ, Corti B, Jalleh G: The myth of "healthism" in organized sports: implications for health promotion sponsorship of sports and the arts. Am J Health Promot 1997, I I:169-76.

32. Koplan JP, Powell KE: The Olympic Games: opportunities for health promotion. Am J Health Promot 1996, I I:8-9.

33. Moodie R: Measuring the effectiveness of health promotion policy: what can be learnt from Australian success stories? Promot Educ 2004, I:28-32. 49

34. Mendoza J: The war on drugs in sport: a perspective from the front-line. Clin J Sport Med 2002, I 2:254-8.

35. Noakes TD: Improving performance and promoting health by sports participation. Orthopade 2000, 29:972-80.

36. Pikora T, Phang JW, Karro J, Corti B, Clarkson J, Donovan RJ, Frizzell $S$, Wilkinson A: Are smoke-free policies implemented and adhered to at sporting venues? Aust N Z J Public Health 1999, 23:407-9.

\section{Pre-publication history}

The pre-publication history for this paper can be accessed here:

http://www.biomedcentral.com/1471-2458/6/47/prepub

\section{Publish with Biomed Central and every scientist can read your work free of charge}

"BioMed Central will be the most significant development for disseminating the results of biomedical research in our lifetime. "

Sir Paul Nurse, Cancer Research UK

Your research papers will be:

- available free of charge to the entire biomedical community

- peer reviewed and published immediately upon acceptance

- cited in PubMed and archived on PubMed Central

- yours - you keep the copyright 